The Third Pole: Journal of Geography

Vol. 20 - 21: 59-70, 2021

DOI: https://doi.org/10.3126/ttp.v21i01.41618

Department of Geography Education,

Central Department of Education, T.U., Kathmandu, Nepal

\title{
CURRICULUM DEVELOPMENT IN GEOGRAPHY EDUCATION
}

\section{Devi Prasad Paudel ${ }^{1}$}

\begin{abstract}
This paper aims to analyze the historical development of the geography education curriculum. Geography has been occupying an important place since its inception at the Faculty of Education, Tribhuvan University in Nepal. This paper is a review paper. Reviewed materials were collected from different sources, such as official records of the Faculty of Education (FoE), Curriculum Development Centers (CDC) of TU, and archive documents. The findings show that geography has taught as an optional subject at the Bachelor and Master levels in the Faculty of Education. The curriculum covers a broad spectrum of geographic fields, such as physical, human, regional, tools and techniques, and applied concepts, themes, and issues. They are tourism, environments, disaster, climate change, mountains, and so on at both levels. This paper concludes that the curriculum of geography education focuses on content rather than pedagogy. However, it is equally important and necessary to enhance the knowledge on pedagogical content for teachers, educators, educational planners, researchers, and freelancers who are engaged in geography education.
\end{abstract}

Keywords: Geography education, multidisciplinary nature, geography curriculum, semester system, horizontal and vertical integration.

\section{Introduction}

The term curriculum often refers to a planned sequence of instruction or a view of the student's experiences of educator or school's instructional goals. The term curriculum has many definitions, ranging from a plan for and experience by learners across four contexts: curriculum areas and subjects, interdisciplinary learning, ethos, and life of the school, and opportunities for personal achievement. Thus, the curriculum is the totality of experiences planned for children and young people through their education, wherever

1 Dr. Paudel is a Associate Professor, Central Department of Education, Tribhuvan University, Email:devipoudel1@yahoo.com 
they are educated (Scottish Government, 2019). Taba (1962) defined a curriculum as a plan for learning. The curriculum represents a conscious and systematic selection of knowledge, skills, and values: selection that shapes teaching and learning processes organized by addressing questions such as what students should learn, why, when, and how (UNESCO IBE, 2013). Braslavsky (2003) defines curriculum as a foundation of the educational process. It is organized contents in their sequential relation to the amount of time available for the learning experiences, the characteristics of the teaching institutions, the character of the learning experiences, the point of view of methods, the resources for learning and teaching (e.g. textbooks and new technologies), evaluation and teachers' profiles.

Based on the above definition, the curriculum is the overall outline of any educational program. The scientific study of geography began after Kant, Humboldt, Ritter, Peschel, and Ratzel in the 19th century. They defined the scope and content of the subject to develop geography as a scientific discipline (Martin, 2005). The curriculum is also essential to teach geography at the school and higher levels. There is no single, unified discipline of geography today and it is difficult to discern such a thing in the past (Clifford, Holloway, Rice \& Valentine, 2009). They argued that physical geographers understandably perceive themselves to be working in a very different historical tradition from human geographers, while the many perspectives employed on either side of this crude binary division also have their own peculiar historical trajectories (p. 3).

Geography Curricula, by its nature, are varied and multiple, with different countries often privileging different types of geographical knowledge and skills (Brian; Sanders; Robin, Michaela \& Paul, 2011). The curriculum of geography has influenced by continuing and changing needs of the individual and society. Curriculum development is the process of translating educational objectives into the course content and educational strategies. The curriculum sequence is concerned with the appropriate order of the topics and subtopics over time. The continuity of curriculum refers to a logical program over time without any gaps (Blank, Van der Sheet, Volman \& Boogaard, 2016).

The curriculum development process is a very difficult task in geography education. It is mainly due to geography does not lead to one clearly identifiable concept which lies at the heart of the discipline(Clifford, Holloway, Rice \& Valentine, 2009).However, geographic concepts, themes, and traditions are important sources of the curriculum in geography education at different levels. These are space, place, time, scale, landscape, nature, systems, globalization, development, and risk. Geographic concepts, themes, and traditions have addressed in the everyday life of human beings as well (John, 1989). It deals with human-environment relationships, spatial patterns, and processes. 
The geography curriculum has produced different types of knowledge based on core and content. Rwanda Education Board (2020) summarizes the difference between Knowledge-Based Curriculum (KBC) and Competence-Based Curriculum (CBC). According to the Board, the former focuses on subject content that learners can know and memorize rather than what they can do. The latter focuses on what learners can do and apply in different situations by developing skills, attitudes, values, knowledge, and understanding.

Jones (2004) argues that the geography curriculum is essential to trainee teachers for understanding the impact of the Geography National Curriculum (GNC) at KS3 (Kindergarten to standard 3). He concludes that the geography curriculum should cover concepts, themes, and geographic skills, fieldwork, using and making maps, using photographs, using ICT, problem solving, and decision-making.

Lambert and Morgan (2010) have reviewed the development trends of geography education since the post-world war period. Their finding shows that the early geographical knowledge based on racial differences in a colonial imagination at the end of the $1800 \mathrm{~s}$. The geographic thinking more focused on environmental determinism framed within a regional approach in the nineteenth century and shifted into a systematic approach in the 1960s. The geography curriculum adopted a consensual model of society that favored the role of geographer as 'technocrat', fixing the problems of industrial society in the 1970s and early 1980s. After the 1980s, World Studies tended to operate with a much broader sense of what development means, infused by a non-governmental organization (NGO) thinking and new "value-based pedagogical approaches. It means geography has become increasingly concerned with global issues in the past decade, and the dimension is evident in the curriculums at various levels.

The geography is considered the past social event and development stages being gradually in the world history. The evolution of geography curriculum is based on two views, American and British in the world. Both countries had strong tradition of work on these topics and many geographers had academic roots in the associated field of geology (Johnson, 1989). Geography could neither claim it as natural science nor as a social science subject. This was the source of much confusion in the formative phase of geography as a modern discipline in the nineteenth century when division of knowledge into distinct disciplines was being concentrated (Dikshit, 1999).

In India, geography teaching was first started from the University of Punjab (1920) and Patna in 1920 and 1927 respectively in Under Graduate and Post Graduate levels (UGC, 2001; Hassan, 2017). The Curriculum Development Committees of India has upgraded 
courses introduced to acquire the expanded knowledge, which is of relevance to the modern society, such as physical geography, human geography and regional geography, application of information communication technology, and fieldwork (Nangia, 2001). The early geography curriculum of Nepal based on the curriculum of Indian school and university (Subedi, 2014). After the establishment of Tribhuvan University, Nepalese geographers has been involving teaching and research in geography. Since geography has become an established subject of the university, the curriculum development of the university teachers seems to be an important task.

Geography covers an array of concepts relating to physical and human dimensions. The concepts organized into themes and traditions for curriculum development at different levels. These matters deepen students' knowledge and broaden their understanding of the discipline to think geographically. It requires a balance between the acquisition of knowledge, skills and understanding in curriculum. The subject matters of geography have comprised ancient colonial, regional, modern, and postmodern ideas, theories, and methods. It draws attention to select these concepts, themes, and traditions in the curriculum to teach at different levels. In this context, the purpose of this article is to review how Bachelor and Master Levels of the Faculty of Education organized these matters in geography curriculums.

\section{Methods and Materials}

This paper is mainly of descriptive in nature and based on secondary sources of information. Most of the information were collected from documents and publications related to curriculum published by Dean's Office, Faculty of Education, Tribhuvan University. Similarly, related archived documents like books and journal's articles were also reviewed to analyze the historical context. Besides, relevant information/data were acquired from digital sources.

\section{Results and Discussion}

Importance of Curriculum: The concept of curriculum is broad. It consists of the totality of experiences that a pupil receives through the many-fold activities in the classroom and other numerous contacts between the teachers and the pupils. The curriculum plays a significant role in teaching geography. It is a blueprint, which leads the teacher and the learner to reach the desired objectives. Geography teachers design the curriculum by incorporating four components, such as objectives, contents or subject matters, teaching methods, and evaluation of learning outcomes. It depends upon the level of students, the need of society, and the nation. The nature of the content is a very influencing factor. These factors are essential in identifying the objectives of teaching learning. Teachers 
are open to set several types of teaching objectives to attain desirable outcomes from the same content. Content has its structure. The specific objectives facilitate organizing teaching tasks and activities.. There are four elements in the curriculum -a) aims and objectives, b) content or subject matter, c) learning experience, and d) evaluation, which are equally essential and interrelated to each other. The Bachelor and Master's levels curriculum of Education Geography have also included the following components: general objectives, specific objectives, contents, teaching methods, and evaluation to assess learning outcomes.

Geography includes various subject matters and activities to enable students' knowledge, skills, and understanding of the relationships between human and their environment. They know the basic principles of geography and increase a commitment to participate in societal activities. Thus, the curriculum is a primary vehicle for achieving the goals and objectives of teaching geography at various levels.

Typology of Curriculum: The curriculum reflects the models of instructional delivery chosen and used; some might indicate that curriculum could be categorized according to the psychological classifications of the four families of learning theories, such as social, information processing, personalist, and behavioral. Therefore, each curriculum is defined based on its unique type, which helps teachers to focus on epistemic quality. Ebert, Ebert, and Bentley (2013) identified explicit, implicit, null, and extra curriculum. Each curriculum has characterized a specific perspective that intended to supplement the academic aspect of the school experience. Toohey (1999) identified five approaches to curriculum design based on particular philosophical and epistemological perspectives. These are systems-based approach, a cognitive approach, an experiential or personal relevance approach, and a socially critical approach, which are used in curriculum development. The most common was a traditional discipline-based approach, which gives a structured approach to discipline-based knowledge and skills.

Development of Geography curriculum in Nepal: The development of geography curriculum in Nepal started from early in the twentieth century. Jaya Prithvi Bahadur Singh (1993) was the first contributor to prepare curriculum of geography at school level in 1901. In University, geography subject was started at Tri-Chandra colleges in 1947 at intermediate level and bachelor's degree in 1949. The Department of Geography was established in 1960 under the faculty of Humanities and Social Sciences at Tribhuvan University, Kirtipur. However, curriculum development in geography education is relatively new as compared to Department of Geography. Teaching geography education was started from two-years Bachelor of Education (B.Ed.) programs in Faculty of Education, after the implementation of the New Education System Plan in 
1971 (Adhikari, 2010; Lamichhane,2005; Pandey, 1998). After two decades of teaching geography in education, the Master level was started only from 1992.

Before the introduction of National Education System Plan (NESP), geography was taught as a compulsory subject in the school level curriculum and it was become a part of social studies after the introduction of NESP in 1971. In the 1980s, the school level curriculum revised and bring down from 900 Marks into 700 Marks, as a result, geography was put as an optional subject. This change seems to be pushing to the margins as geography is unable to compete with other elective subjects at the school level such as mathematics, science, accounting, etc. This situation seems to be increasing rapidly after the phase-out of proficiency certificate level from the Tribhuvan University. However, in the recommendation of the Education Commission of 1992, the concept of geography has incorporated as a part of social studies.

The National Curriculum Framework 2018 has included the concepts of geography from classes 1 to 12 in social studies curriculum. Indeed, geography is still an elective subject in the secondary level. It shows that the horizon of geography education is gradually scaling down at both the school and university levels. In order to fulfill the needs, the school level geography curriculum seems to include different aspects related to physical, human, economic, regional, and tools and techniques since its initiations.

Geography Education curriculum: In Nepal, the geography education started to teach at B.Ed. program since 1956 in Tribhuvan University. After the New Education System Plan as in other levels, curriculum was also revised in 1975 and introduced the semester system. The exiting two years' academic course was divided into four semesters, with 1200 papers of 36 credit hours. The geography curriculum covers physical geography, human/ regional geography, and teaching geography for the major geography area.

Geography education curriculum includes 75 credit hours after the revision of the two years B.Ed. course and 40 credit hours for a one-year B. Ed. in 1978. The Faculty of Education introduced a three-years B.Ed. in 1996 and further revised the curriculum. The three years B. Ed. courses offered physical geography, human and economic geography, regional geography of Asia and Nepal, geographic technique, teaching geography, population, and environmental geography from first to third year (CDC, TU,1996). These courses can be classified into four broader themes of geography, such as systematic studies (physical and human geography), regional studies (geography of Nepal and Asia), tools and techniques (methods of teaching, cartography, surveying, and field study), and applied geography (population and environmental geography). It shows that the geography curriculum has been changing over time. The Faculty of 
Education has introduced a four years' B. Ed. program since 2015. This program has further revised courses of ten subjects for specialization and five subjects for nonspecialization areas. FoE prescribed 22 courses for four years B. Ed. The programs comprising four groups: group 'A' communication skills, group 'B' professional core areas, group ' $\mathrm{C}$ ' specialization major courses and, group ' $\mathrm{D}$ ' specialization minor courses. Group 'E' includes teaching practice/practicum. Minor subjects' area open for all students and students can select minor subject area that should be different from their major subject area (Table 1).

Table 1: Major courses offered for four-year B. Ed. program

\begin{tabular}{|c|c|c|c|}
\hline Year & Major Subjects & $\begin{array}{c}\text { Minor Subjects } \\
\text { (with separate codes) }\end{array}$ & Marks \\
\hline \multirow[t]{2}{*}{ First } & Physical Geography & Physical Geography & 100 \\
\hline & Human Geography & & 100 \\
\hline \multirow[t]{3}{*}{ Second } & $\begin{array}{l}\text { History of Geography and } \\
\text { Geographical Thought }\end{array}$ & $\begin{array}{l}\text { History of Geography and } \\
\text { Geographical Thought }\end{array}$ & 100 \\
\hline & World Regional Geography & World Regional Geography & 100 \\
\hline & $\begin{array}{l}\text { Geographical Information } \\
\text { System and Remote Sensing }\end{array}$ & & 100 \\
\hline \multirow[t]{3}{*}{ Third } & $\begin{array}{l}\text { Methods of Teaching } \\
\text { Geography }\end{array}$ & & 100 \\
\hline & $\begin{array}{l}\text { Economic Geography and } \\
\text { Resource Management }\end{array}$ & & 100 \\
\hline & Geography of Nepal & Geography of Nepal & 100 \\
\hline \multirow[t]{2}{*}{ Fourth } & $\begin{array}{l}\text { Geography of Environment, } \\
\text { Hazard and Disaster } \\
\text { Management }\end{array}$ & $\begin{array}{l}\text { Geography of Environment, Hazard } \\
\text { and Disaster Management }\end{array}$ & 100 \\
\hline & Geographical Techniques & & 100 \\
\hline Total & 10 subjects & 5 Subjects & \\
\hline
\end{tabular}

Source: Dean Office, 2015

Table 1 shows the course offered by geography education in four years B. Ed. Program. The table indicates that out of the total number of only two comprises practical. The courses are comprised of physical geography, human geography, geographical thought, Geographical Information systems (GIS) and Remote sensing (RS), world regional geography, the geography of Nepal, and geography of environment, hazard, and disaster management for both specialization and non-specialization areas.

The Geography Education Curriculum at Master Level: The geography education courses at the graduate level have offered under the Geography Instructional Committee for a long time. However, the Masters' degree in geography education program started 
in 1992 and the instructional committee restructured into the Department of Geography Education in 1994. The Master's in geography education covers both contents, pedagogical aspect of teaching geography, course works, thesis writing, and field works (practical and practicum). FoE has been introduced a semester-based Master of Education (M.Ed.) and revised the existing curriculum in 2015 with 22 courses. These courses carry 69 credit hours and are allocated 21 credit hours for the educational core area, 39 credit hours for the specialization area, and thesis and practicum nine credit hours.

Out of the total 39 credit hours courses of geography, the content course covers advanced physical geography, advanced human geography, geographical thought, advanced geographic technique, the geography of tourism, regional geography, thesis, and practicum. Two elective subjects of political geography and geographical information system and remote sensing are also offered at this level. The department of geography education is a leading organization for curriculum development and master of education in geography courses in the country (Third pole, 1993). In 2015, the Faculty of Education introduced a four-semester program at the Master's level. Semester-based geography education offered both theoretical and practical courses (Table 2).

Table 2: Course offered at M.Ed. program

\begin{tabular}{|c|c|c|c|}
\hline Semesters & Course title & Full Marks & Nature of Course \\
\hline \multirow[t]{4}{*}{ First } & Geomorphology & 100 & Theory \\
\hline & Population Geography & 100 & Theory \\
\hline & Geographical Thought & 100 & Theory \\
\hline & Mountain Geography & 100 & Theory \\
\hline \multirow[t]{4}{*}{ Second } & Climatology and Climate change & 100 & Theory \\
\hline & Applied Statistics for Geographic Research & 100 & Theory \\
\hline & $\begin{array}{l}\text { Geographic Information System (GIS) and } \\
\text { Remote Sensing(RS) }\end{array}$ & 100 & Theory and Practical \\
\hline & Geography of Resource Management & 100 & Theory \\
\hline \multirow[t]{4}{*}{ Third } & Teaching Geography & 100 & Theory and Practical \\
\hline & Surveying, Cartography and Field Study & 100 & Theory and Practical \\
\hline & Regional Study with Reference to Nepal & 100 & Theory \\
\hline & Geography of Tourism & 100 & Theory \\
\hline \multirow{4}{*}{$\begin{array}{l}\text { Fourth } \\
\text { (any one } \\
\text { from the } \\
\text { group) }\end{array}$} & Environmental Geography & 100 & Theory \\
\hline & Agricultural Geography & 100 & Theory \\
\hline & Settlement Geography & 100 & Theory \\
\hline & Total 15 subjects & & \\
\hline
\end{tabular}

Source: Dean Office, FoE, 2015 
Table 2 reveals that the offering subject of master level geography education on TU. The table indicates that twenty-two papers are offered including compulsory and optional papers. Geomorphology, history of geographical thought, population geography, and mountain geography are prescribed subjects for the first semester. These subjects have particularly focused on physical and human geography including evolution of geographical thought. Geomorphology and mountain geography are associated with the physical portion and the population geography is associated with human geography. Climatology and climate change, applied statistics for geographical research, the geography of resources management, GIS and RS are included in the second semesters. The subject of the second semester is more technical and applied in nature. Similarly, teaching geography, surveying cartography, and field study, regional study with reference to Nepal, and geography of tourism are prescribed for third semester. Similarly, environmental geography, agricultural geography, and settlement geography are included in the fourth semester as optional papers. Only one subject can be selected from this group. Beside this, a thesis paper with two hundred full marks and teaching practice are compulsory in the fourth semester for the students in geography education.

Content knowledge and Pedagogical knowledge: The Master's level courses cover both content and pedagogical content knowledge. The study of the art and science of teaching is called pedagogy. It is very important for teaching to the teachers. Three kinds of knowledge are essential for effective teaching: knowledge about the subject matter (content knowledge), knowledge of general instructional strategies (pedagogical knowledge), and knowledge of specific strategies for teaching a particular subject matter (Pedagogical Content Knowledge) (Cochran, Deruiter \& King, 1993; Shulman, 1987 Cited in Jeanne \& David, 1996). According to them, knowledge of the world's expanding rate and understanding effective educational practice continually modified and refined, teachers must regularly update their knowledge about content and pedagogy. Geography is a discipline for which many teachers should have pedagogical knowledge. Based on the factors mentioned above, point to the necessity for teaching both content knowledge and pedagogical knowledge in geography is essentials for those who are involved in teaching geography according to geography curriculum.

Evaluation System: This semester system focuses on continuous assessment system and regular monitoring of students' progress. The semester system develops both internal (40 marks) and external (60 marks) evaluation systems to assess learning outcomes. This internal evaluation system consisting of attendance, classroom activities, first, second and third assignments provided by the teacher.

Examination system of faculty of education conducts the external evaluation system. It is designed to assess the student's learning outcomes routinely as; 10 points from 
objectives questions, 30 points from short answer type and 20 points from long-answer questions. However, the examination is held annually by the office of the controller of the examination board for B.Ed. level. For the master level final examination is under the responsibility of Dean's Office. Teaching practice and thesis writing are compulsory at the Master's level.

Horizontal and vertical integration of Curriculum: The organization of curriculum by different levels and with other disciplines also influenced the students' learning outcomes. Learning proceeds from simple to complex and from known to unknown. The curriculum design in geography education has also considered these principles to select content at various levels by integrating horizontal and vertical linkage. It is mainly due to geography covers a broad spectrum of knowledge, skills, and understanding. The selection of subject matter for the B. Ed. level requires previous knowledge of secondary level geography curriculum and the Master's level course based on the B.Ed. level courses. This is known as vertical linkage and the learning of geographic knowledge supported by other disciplines taught at the same level is known as horizontal linkage. The relationship of vertical and horizontal is vary depending on the nature of subjects.

The analysis reveals that the fourth-semester curriculum of environmental geography is not enough for the bachelor levels course of Geography of environment, hazard, and disaster management. The master level course of environmental geography is associated with the environment, hazard, and disaster management. However, the hazard and disaster management portions are not in detail as compared to the bachelor level. The content of environmental geography- hazards, vulnerability, disaster risk, disaster risk management, disaster preparedness, disaster response and recovery, disaster resilience, prevention and mitigation are important to be incorporated in geography education to make it more relevant with the present context of Nepal.

\section{Conclusions}

The curriculum is a vehicle for teaching learning geography. The development of geography curriculum has a long history in Nepal. The curriculum development process has been associated with the establishment of Tri-Chandra College (1947), College of Education (1956), Central Department of Geography (1960) and inspection of Master's in geography education (1992). However, the designing of curriculum has also influenced by the neighboring countries curriculums and contemporary socio-political situation of the country. The finding of this paper shows that geography curriculum is based on the geographic concepts, themes and contemporary traditions. The curriculum organized into four themes, such as systematic study, regional studies, tools and techniques and applied geography. There are global issues around neoliberalism, globalization, climate change, 
inclusion, exclusion, gender, disaster and risk, however, the geography curriculum focuses on people, place, and environment of changing society. The curriculum of B.Ed. and M.Ed. geography has changed over time.

\section{References}

Adhikari, J. (2010). Geographical education and research in Nepal. Social science Baha, Kathmandu, Nepal: Baha Occasional Papers.

Blank, M. Van der Sheet, J. Volman, M. \& Boogaard, M. (2016). Design \& development of a geography curriculum for first year primary student teachers. Netherlands: Curriculum and Teaching, 31(2), pp...

Brian, W.W; Sanders, A.; Robin, A.L. Michaela, B; \& Paul, C. (2011). Curriculum development: Producing Geographers for the $21^{\text {st }}$ century. Indian Journal Geography in Higher Education 35 (3), Pp. 379-393. doi. org./10.1080/03098265.

Burathoki, J. B. (1993). The teaching of geography in our school. Geographer's Point Journal of Geography, 2 (2), pp. 22-26. Kathmandu: Centre for Nepalese Geography.

Clifford, N. J., Holloway, S. L., Rice, S. P. \& Valentine, G. eds. (2009). Key concepts in geography. London: SAGE Publications Ltd

Curriculum Development Centre (CDC) (1996). Three years B.Ed. programs. Faculty of Education, TU, Kirtipur Office of the Deans. Curriculum Development Centre.

Curriculum Development Centre (CDC) (2015). M. Ed. semester programs. Faculty of Education, TU, Kirtipur Office of the Deans. Curriculum Development Centre.

Dikshit, R.D. (1999). Geographical thought: A contextual history of ideas. New Delhi: Printing Hall of India Pvt.

Ebert, E. S., Ebert, C., \& Bentley, M. L. (2013). Curriculum Definition. Retrieved from http://www.education.com/reference/article/curriculum-definition/.

Hassan, M. (2017). The role of teaching geography in Indian School Curriculum. Jadavpur University India: IJARIIE Vol. 3 (6),

Jeanne, E.\& David, B.C. (1996). Teaching Content Knowledge and Pedagogical Content knowledge: A Model from Geographic Education. University of Northern Colorado. 47, Issue 10 , page(s) 37-42.https//doi.org/10.1177// 0022487196047001007.

Johnston, R. J. (1997). Geography and Geographers: Anglo- American Human Geography since 1945. London: Oxford University Press.

Johnston, R.J. (1989). Philosophy, ideology and geography. In Derek Gregory and Rex Walt ford (Eds.), Horizon in human geography. London: MACMILLAN Press Ltd.

John, E. (1989). The geography of everyday life. In Derek Gregory and Rex Wilfrid (eds.), Horizons in human geography. London: MACMILLAN Press. 
Jones, M. (2004). Working with the National Curriculum. In Smith, M. ed. (2004). Aspects of teaching and learning in secondary schools: Perspectives on practice, pp. 3-23. New York: Routledge.

Lambert, D. \& Morgan, J. (2010). Teaching geography 11-18: A conceptual approach. New York: Open University Press McGraw-Hill Education.

Lamichhane, D. B. (2005). Geography in school and higher education. In Subedi, B.P. and Poudel, P.C. (Eds.). Geography and geography works in Nepal: Reflection on mountain environment and human activities. Nepal geographical society, central Department of Geography and National centre of Competence in Research North-South, pp. 167- 175.

Martin, G. J. (2005). All possible worlds: A history of geographical ideas. New York: Oxford University Press.

N. A. (1993). Geography for all. Department of Geography Education, Faculty of Education, TU Nepal: The THIRD POLE, Journal of geography education, 1, pp. 78-82.

Nangia, S. (2001). Curriculum Development Committee in Geography. India: CDC in Geography. Republic of Rwanda (2020). Rwanda Basic Education (REB) Ministry of Education, Rwanda retrieved fromwww.reb.rw

Scottish Government (2019). What is Curriculum for Excellence? - Education Scotland. Retrieve from https://education.gov.scot > policy-drivers > what-is-cur

Rwanda Education Board (2020). Foundations of education for the student's book. Retrieve from www.cedefop.europa.eu.

Subedi, B. P. (2014). The state of geography teaching and research in Nepal: A review and Reflection. Kathmandu: Martin Chautari.

Subedi, B.P. (2005). A glimpse of geographic research in Nepal: Review and reflection. In Subedi, B.P. and Poudel, P.C. (eds.), Geography and geography works in Nepal: Reflection on mountain environment and human activities. Nepal geographical society, central Department of Geography and National centre of Competence in Research North-South, pp. 85- 103.

Taba, H. (1962). Curriculum development: Theory and practice. New York: Harcourt, Brace \& World.

Toohey, S. (1999). Designing Courses for Higher Education. Buckingham: The Society for Research into Higher Education \& Open University Press.

UNESCO, (2013). IBE UNESCO International Bureau of education. Retrieve from http://ibe.unesco.org/fileadmin/userupload/Publications/Institutional Docs/ IBE_brochure_2013_eng.pdf).

University Grant Commission (UGC) (2001). Report on the curriculum development committee in geography. New Delhi, India: University Grant Commission (UGC). 